\title{
sciendo
}

\section{Destination authentic value advantage: an SDL perspective}

\author{
Augusty Tae FERDINAND \\ Faculty of Economics and Business Diponegoro University, Diponegoro, Indonezia \\ augusty@live.undip.ac.id
}

\begin{abstract}
This study aims to build a destination marketing conceptual model to bridge the research gap concerning managing a destination service-scape quality for enhancing destination loyalty. The convenience sample data were collected from an unknown population of Indonesian domestic tourists who visited tourist destinations in Indonesia. Data were analysed using AMOS SEM Software. The findings demonstrate the significant impacts of destination servicescape quality on destination authentic value advantage. The research findings resulted in a complete significant pathway to enhancing loyalty by mediating an authentic destination advantage through destination congruence. This study is evidence for the application of SDL-Service Dominant Logic Theory. The possibility of enhancing an authentic value experience superiority would be a strategic process for achieving any level of destination congruence as a step towards creating and sustaining loyalty. Destination planning could consider crafting the hardscape and soft-scape of a destination equally. A company should provide services that encourage positive emotions as the basis for building congruency. The originality of this study is the concept of destination servicescape quality with two new dimensions of destination service, hard-servicescape and soft-servicescape, and the development of destination authentic value advantage for enhancing authentic value advantage.
\end{abstract}

Keywords: servicescape, authentic value advantage, destination congruence, informational service completeness, destination loyalty.

Please cite the article as follows: Ferdinand, A. T., (2021), "Destination authentic value advantage: an SDL perspective", Management \& Marketing. Challenges for the Knowledge Society, Vol. 16, No. 2, pp. 101-117, DOI: 10.2478/mmcks-2021-0007.

\section{Introduction}

Studies on destination and tourism marketing have been popular in this decade. Scholars in tourism marketing have carried out empirical studies from consumer perspectives, such as searching for and consuming the destination values. Those studies could be categorised by research viewpoint, first as studies on destination value attractiveness (Cracolici \& Nijkamp, 2009; Mikulić, Krešić, Prebežac, Miličević, \& Šerić, 2016; Saikia, Buragohain, \& Choudhury, 2019; Tosun, Dedeoğlu, \& Fyall, 2015) and, second, as studies on the completeness and readiness of a destination for attracting visitors (Akroush, Jraisat, Kurdieh, Al-Faouri, \& Qatu, 2016; Chang, F. Backman, \& Chih Huang, 2014; Sangpikul, 2018). As our research focuses on marketing a destination, particularly the destination's ability to attract visitors, we assume two main factors as strategic inputs for visitors to determine to visit a destination. First, destination servicescape is a leverage factor for destination attractiveness (Lockwood \&

DOI: $10.2478 / \mathrm{mmcks}-2021-0007$ 
Pyun, 2020; Tosun et al., 2015); second, destination value is a central point of consumption attractiveness (Alazaizeh, Hallo, Backman, Norman, \& Vogel, 2016; Kim, Seo, \& Nurhidayati, 2019).

Studies by Hossain, Quaddus, and Shanka (2015), Tosun et al. (2015), and Kaushal, Sharma, and Reddy (2018) show that excellent destination servicescape quality is not always significant leverage for visitor loyalty or, at least, a visitor's willingness to recommend a destination to others. Destination marketing studies have also discovered value as one of the leading destination working concepts, which do not always impact destination loyalty (Dedeoğlu, 2019; Sangpikul, 2018). Those inconsistent findings lead us to research that seeks any conceptual solutions for bridging the inability of destination servicescape quality to enhance destination loyalty.

We adopted the service-dominant logic approach (SDL) to solve the problem, for several reasons. First, one of the basic SDL principles is that what consumers are looking for or prefer to find is not the physical product or service attributes, but a specific value, glowing and sensed from a destination, leading to the notion of value creation as the key factor in attracting consumer decisions (Greer, Lusch, \& Vargo, 2016; Vargo \& Lusch, 2017). Second, value as a destination's key factor should have the power to attract visitors, such as consumers co-creating the value or benefit to sustain performance (Evans, 2016). Therefore, in adopting the SDL perspective, we inserted the following concepts into our conceptual model: destination servicescape quality (DSQ), destination authentic value advantage (DAVA), informational service completeness (DIC), destination congruence (DC), and destination loyalty (DL). The current study aims to propose a conceptual model for managing consumer-side destination marketing to bridge the research gap in the literature on the ability of destination servicescape quality to enhance destination loyalty. The current study aims to propose a conceptual model for managing consumer-side destination marketing to bridge the research gap in the literature on the ability of destination servicescape quality to enhance destination loyalty. The model then was tested using the Indonesian tourism destination.

\section{Literature review and model development}

\section{Destination servicescape quality and authentic value advantage in the SDL perspective}

One pivotal SDL point of view is that marketing is about value co-creation (Vargo \& Lusch, 2017) through several processes, such as value co-creation that might indirectly involve consumers in configuring value through the process of collecting consumer voices. In the tourism consumption process, value creation should not be seen as a continuous process by adding or deleting value elements based on the continuous experience process value of past consumers. As mentioned in the study by Correia, Zins, and Silva (2015), a tourist can rationally spend his/her resources, preferably in diverse consumption, instead of repeating the same product or service, with less likelihood of returning to the destination visited before, except when there is a very specific value in the service-offerings list.

As proposed in this study, destination servicescape quality (DSQ) comprises twodimensional concepts, hard-servicescape, and soft-servicescape, describing all tangible attributes of a destination and intangible social attributes, indicated by the ease of getting and affording an accommodation-hotel and restaurant (Richardson, Lefrid, Jahani, Munyon, \& Rasoolimanesh, 2019). Another hard-servicescape is the attractiveness of events and destination-related activities (Akroush et al., 2016; Alazaizeh et al., 2016). Included in hard- 
servicescape quality is the support for money and banking needs, such as availability and safety of ATM or money changers for tourists (Dedeoğlu et al., 2019), and the social environment of the destination. We conceptualise the soft-servicescape of a destination as a portfolio of social, intangible servicescape attributes that have the potential to raise a positive emotional feeling. A soft-servicescape may elicit that experience with a symbolic artifact that creates good first impressions or friendliness and hospitality, resulting in primary emotional responses, such as pleasure and arousal(Dedeoğlu, 2019). A soft-servicescape may arise when a tourist attaches an ambient response to an experience of social interaction (Tran Quynh, Dang My, \& Tournois, 2020) with local people at the destination. Receiving polite responses, support, and feelings of friendship in a destination enhances positive emotions, such as excitement, happiness, and energy (Tubillejas Andrés, Cervera-Taulet, \& Calderón García, 2016); this experience may result in a kind of brand love (Ferreira, Rodrigues, \& Rodrigues, 2019) to a visited destination.

Our critical question is: What process should occur if destination servicescape quality were adopted as a strategic marketing instrument for leveraging destination loyalty? Adopting the SDL point of view, the current study proposes a direction for servicescape quality to accentuate value superiority through experiencing the destination servicescape. Previous studies provide insights into values that drive visitors to expand a visit, attributing loyalty to experiencing superior preservation value (Alazaizeh et al., 2016), better authenticity (Fu, 2019), experiencing any aesthetics attributes as an engaging and motivating tool for purchasing and loyalty behavior (Haziri, Chovancová, \& Fetahu, 2019) particularly for a heritage destination spot. As authenticity is critical to service success, particularly in a tourist destination, the capability of developing an authentic value should be prioritised in the process of configuring any aspect of authenticity for a destination. When a company or an organisation has a specific ability to configure a series of value attributes through placespecificity, those specifics will lead to creating destination authenticity. They could attract visitors to experience the value they provide, enhancing the possibility of resonating with and revisiting this type of value-oriented destination. Therefore, any specific memory accumulated through experiencing destination specificity will lead to a sense of specific experiential value as a driver for revisiting the destination. A superior destination experience may come from several attributes that hold the potential to stay in the consumer's memory box for a long time, as the enjoyment of newness or an epistemic experience (Suhartanto, Brien, Primiana, Wibisono, \& Triyuni, 2019), in the sense of enjoying something new and acquiring a special sense of the visit. Moreover, the feeling of a destination advantage should come from experiencing any distinctiveness through memorable uniqueness (Zhang \& Xu, 2020). The superior authenticity of a destination physically appears as the better preserved historical architecture, the specific authentic portrayal of social life, uniqueness in local history and culture (Lu, Chi, \& Liu, 2015) that may stay longer in the visitor's mind as a special, memorable value, due to the quality of enjoyment of a servicescape.

Authentic value advantage of a destination may manifest as the superiority of certain attributes of a destination that emerge in several ways, such as a cutting-edge concept of enjoyment in a destination (Zhang, $\mathrm{Wu}, \&$ Buhalis, 2018), specific cultural events, spectacular natural scenery, ethnic-specific handmade souvenirs, an instagramable, photogenic spot or out-of-the-box landscaping, sacred ambiance and spiritual events, local fauna and flora, which could boost a positive sense, emotion and memory of a destination. 
The social environment is all social attributes of a destination, such as friendliness, trusting interaction, or a supportive community (Ramkissoon \& Nunkoo, 2011). If a visitor comes and has good experience with those destination servicescape attributes, management can anticipate a positive feeling about the destination value to function as a trigger for a longterm consumption memory. When a good or superior servicescape quality is experienced during a visit to a destination, the good feeling will maintain the value of the destination, such as sensing its authenticity, memories of the experience, enjoyment of the flora and fauna in the surroundings, and all specifics tried and enjoyed that would remain in the visitor's mind as superior, memorable enjoyment. Therefore, the following first hypothesis is proposed.

H1: Destination servicescape quality positively influences the destination authentic value advantage.

A visitor comes to a tourism spot to enjoy the specifics of an authentic destination. If those are consumed and sensed as a kind of advantage that was better than previous experiences, this enjoyment would enhance positive emotion, in the form of an exciting impression of a happy and energetic visit (Tubillejas Andrés et al., 2016), as a stepping stone to leveraging loyalty to the destination. As referred to Hunt and Arnett (2006), when a consumer feels any comparative advantage of a destination, as a result of comparative resources the destination management deployed, from the consumer's point of view, any comparative superiority of the destination resource would lead to remembering advantages whose potential resides in the capacity to foster a revisit. More specifically, a destination's authenticity advantage, mirrored by sociocultural specifics, would directly impact visitors' decisions to return (Thomas-Francois, von Massow, \& Joppe, 2017). As appeared in the study of Sharma and Nayak Jogendra (2019), if a destination attributes may enhance a kind of emotional value, such as coming from a level of authenticity in a destination leads to a feeling of satisfaction and loyalty. The economic rationale will lead tourists to maximise the money spent by visiting other new places, but if a visited destination can provide an emotional value advantage, then drive a tourist to echo the value it has experienced and leverage loyalty behavior. Therefore, the following second hypothesis is proposed.

H2. Destination authentic value advantage has a positive influence on loyalty to the destination.

\section{Destination congruity: impact of destination authentic value advantage.}

As mentioned, if the consumer perceives destination value authenticity as something better when compared to others, this advantage could become destination capital (Ziakas, Shipway, \& Boukas, 2012), in the sense that any perceived advantages will stay in the mind of consumers or visitors, leveraging an attitude of loyalty and action towards a destination, such as feelings of congruity and willingness to recommend. Feelings and memories of a destination advantage due to any distinctively unique experience (Zhang \& Xu, 2020) and hold potential for enhancing the consumption memory. As discussed in depth in the SDL, a consumer is searching for any specific value offered in the marketplace as a result of destination value co-creation that succeeds in attracting consumer attention and buying decisions (Vargo \& Lusch, 2017) The reason that a consumer decides to buy could be explained as a result of feeling congruity-matching the perceived image of a destination and the tourist's self-image (Ahn, Ekinci, \& Li, 2013). A theoretical explanation for why a 
consumer has a feeling of congruity is that when a destination provides enough room to experience all value specifics at that destination, the experience leverages an emotional feeling and attachment to that destination, known as congruity.

Destination congruence emerges when consumers find a good match between the superior value they experience and its fit for themselves (Sirgy, 1982; Sirgy \& Su, 2016). Destination congruence exists if the destination's image is consistent with the tourist's selfimage. For example, a Bali beach resort's image in Indonesia, as one of the favorite world destinations, is quiet, serene, and peaceful with nice weather. If that matches the tourist's ideal self-perceived personality, it reaches a level of destination congruity (Shin, Lee, \& Perdue, 2018). In a nutshell, the SDL perspective is a theoretical foundation for explaining the destination's value congruence with any visitor, as a basis for enhancing destination loyalty, if a created value succeeds in configuring attributes that the visitor perceives as superior. Therefore, the following third hypothesis is proposed.

H3. Destination authentic value advantage has a positive influence on destination congruity.

\section{Informational service completeness and destination servicescape quality}

Information completeness would facilitate the prospective tourist's self-confidence about visiting the destination, enhancing the cognition, affection, conation for experiencing a destination (Choi \& Wu, 2018). As mentioned by Lojo, Li, and Xu (2020), such information tools as guides and blogs adapted to resonate with the value or image of a destination, are a crucial factor for a visitor considering a destination, holding the potential to enhance the congruence of the destination with the visitor. Good and precise information on a destination, clearly broadcasted as in printed or digital brochures, is necessary for facilitating tourists' coming to a destination (Oviedo-García, Vega-Vázquez, Castellanos-Verdugo, \& OrgazAgüera, 2019). As emphasised in marketing communication research, the role of communication is resonating with the good and precise value of the product or service (Botschen, Promberger, \& Bernhart, 2017). After completing a visit, any experiences of the information service completeness and quality will lead to a positive memory of the helpfulness of all supports at a destination. The positive memory may reflect information credibility as a key driver in building a degree of fit and congruence with the destination (Rather, Najar, \& Jaziri, 2020). Hence, the following fourth hypothesis is proposed:

H4. Informational service completeness leverages destination congruity.

\section{Destination congruence and destination loyalty}

Destination congruence could be understood as the feeling of a good match between the perceived image of a destination and tourist self-image (Ahn et al., 2013), which may arise for several reasons, such as a good-quality destination servicescape (Oviedo-García et al., 2019) and the experience of an authentic cultural value (Jang \& Ha, 2015) that is better than others. The quality of servicescape has the potential to produce a consumption experience that matches what the consumer is seeking, which will increase chances of value-matching that leads to the growth of destination-value self-congruence matching (Abodeeb, Wilson, \& Moyle, 2015). The self-congruence matching process will become a core value towards loyalty to a certain destination (Liu, Lin, \& Wang, 2012). As revealed in the study of Iordanova 
and Stylidis (2019), experiencing any specific value in a destination will lead to the formation of the affective image as the feelings or emotional responses about a specific tourist destination (Kim, Lehto, \& Kandampully, 2019) that becomes the basis of loyal behavior, in addition to the cognitive image. If value and consumer match, the possibility of recommending to others or positive attitudes toward a destination may follow (Beerli, Meneses, \& Gil, 2007; Sirgy \& Su, 2016). Value-congruity would be capital for sustaining value, mirrored by the degree of destination loyalty (Liu et al., 2012). Therefore, the following fifth hypothesis is proposed.

H5. Destination congruence has a positive influence on destination loyalty.

A certain specific authentic product value of service could resonate, if the company provides a specific servicescape, such as a memorable cultural experience, as a stepping stone for evoking a behavioral intention (Jang \& Ha, 2015), such as revisit or sharing a positive impression of a destination and recommending it to others. Only if a destination could provide a specific destination environment leading to any authentic image perceived and experienced by a visitor(Sirgy \& Su, 2016), then a loyalty behaviour may happen. Therefore, the following sixth hypothesis is proposed.

H6. Destination authentic value mediates the influence of destination servicescape on destination loyalty

As accentuated in the value and congruity proposition of Sirgy and Su (2016), our interpretation applies when tourists experience a level of congruity - a match between destination image, such as an image of a value advantage, and their self-image - that would motivate a revisit to that destination. As described above, economic rationality leads consumers or visitors/tourists to optimise their spending through visit diversity rather than revisiting the same place (Correia et al., 2015) unless they experience a very specific and authentic value advantage. We argue that only a destination with the capacity to offer an authentic value advantage, capable of fostering a feeling of congruity, may establish loyalty. Therefore, the following eighth hypothesis is proposed:

H7. Destination congruence mediates the influence of destination authentic value advantage on destination loyalty.

On the basis of our extant literature review and all developed hypotheses, Figure 1 shows a proposed conceptual model: 


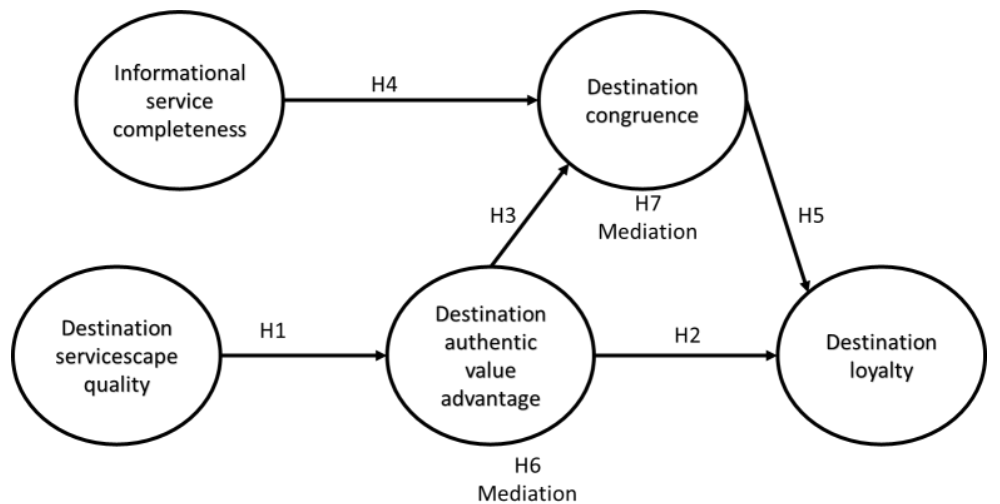

Figure 1. Conceptual model

Source: Authors' own research.

\section{Research Method}

\section{Sample and Respondent}

The data were collected from an unknown population of Indonesian domestic tourists visiting domestic tourist destination in Indonesia. Convenience sampling was conducted to target potential respondents. Our research covers all dominant destinations, Sumatera, Jawa, Bali, Nusa Tenggara, Kalimantan, Sulawesi, Maluku and Papua, covering 344 respondents. In the data-processing stage, 21 respondents provided data with invariability, such as all answers marked with 8 or 10 only. Our final usable data units for further analysis came from the remaining 323 respondents.

Table 1. List of Destination Source

\begin{tabular}{|c|c|c|}
\hline Area Coverage & Frequency & Percentage \\
\hline 1. West part of Indonesia & 168 & $52 \%$ \\
\hline 2. Middle Part of Indonesia & 148 & $46 \%$ \\
\hline 3. East part of Indonesia & 7 & $2 \%$ \\
\hline Total & 323 & $100 \%$ \\
\hline
\end{tabular}

Source: Authors' own research.

This research also explores respondents' value-seeking reasons for visiting those destinations: natural scenery panoramic value, adventure value, historical value, community tourism value, ambiance value, unique cultural value, and social life value, as presented in Table 2.

Table 2. The most attractive tourism spots

\begin{tabular}{|l|c|c|}
\hline Destination Value & Frequency & Percentage \\
\hline Natural Scenery panoramic value & 134 & $41 \%$ \\
\hline Adventurous value & 37 & $11 \%$ \\
\hline Historical value & 34 & $11 \%$ \\
\hline Community Tourism value & 27 & $8 \%$ \\
\hline
\end{tabular}




\begin{tabular}{|l|c|c|}
\hline Ambient value & 21 & $7 \%$ \\
\hline Cultural unique value & 49 & $15 \%$ \\
\hline Social life value & 21 & $7 \%$ \\
\hline Total & 323 & $100 \%$ \\
\hline
\end{tabular}

\section{Measurement}

To conduct this study, we adapted a measurement strategy from several scholars. Destination servicescape quality is adapted from Akroush et al. (2016); (Dedeoğlu, 2019; Sangpikul, 2018; Tosun et al., 2015), comprising five indicators: accommodation, event and attraction, banking support, hospitality, and social environment. Destination authentic value advantage is adapted from studies by Fu, Liu, Wang, and Chao (2018); (Jang \& Ha, 2015; Lu et al., 2015), to build the indicators of superior natural scenery authenticity, superior authenticity maintenance and preservation, a superior collection of flora and fauna authenticity and superior specific authenticity. Destination congruity is adapted from the studies of Ahn et al. (2013); (Shin et al., 2018), with three indicators: self-image fit, feeling of attachment, and congruency effect. Informational service completeness is adapted from the studies of Oviedo-García et al. (2019); (Wang \& Mattila, 2011), with four indicators: cultural info availability, accurate info availability, clear and proper information, and adequate and supportive information. Destination loyalty is adapted from Akroush et al. (2016); (Dedeoğlu, 2019; Sangpikul, 2018; Tosun et al., 2015), for the indicators willingness to recommend, decision for a family visit and frequently revisit. Table 3 presents scale items in the questionnaire. All items were measured using the numerical scale 1-10, with an anchoring technique for achieving a tend to be interval data (Nunnally \& Bermstein, 1994), anchored by 1 at the left side and 10 at the right side. Table 3 presents the description of variables, indicators, scales, measurement estimates, construct reliability and convergent validity.

Table 3. Measurement: Loading factor, Validity, and Reliability

\begin{tabular}{|c|c|c|c|c|c|c|}
\hline $\begin{array}{c}\text { Variable } \\
\text { and } \\
\text { Indicator } \\
\text { code }\end{array}$ & Scales Item & Reference & $\begin{array}{l}\text { Standard } \\
\text { Loading }\end{array}$ & $\begin{array}{c}\text { Critical } \\
\text { Ratio } \\
\geq 1.96\end{array}$ & $\begin{array}{c}\text { CV- } \\
\text { AVE } \\
\geq 0.50\end{array}$ & $\begin{array}{l}\text { CRI } \\
\geq 0.70\end{array}$ \\
\hline \multicolumn{2}{|c|}{ Destination servicescape quality } & \multirow{9}{*}{$\begin{array}{l}\text { Adapted from } \\
\text { Tosun, } \\
\text { Dedeoğlu, \& } \\
\text { Fyall, 2015;, } \\
\text { Dedeoğlu, } \\
\text { 2019; and } \\
\text { Sangpikul, } \\
\text { 2018, } \\
\text { Akroush, } \\
\text { Jraisat, } \\
\text { Kurdieh, Al- } \\
\text { Faouri, \& Qatu, } \\
\text { 2016 ) }\end{array}$} & & & 0.682 & 0.914 \\
\hline \multicolumn{2}{|c|}{ Destination hardscape quality } & & & & & \\
\hline SERV1 & $\begin{array}{l}\text { Ease of getting affordable } \\
\text { accommodation }\end{array}$ & & 0.775 & 11.896 & & \\
\hline SERV1 & $\begin{array}{l}\text { Availability of good } \\
\text { attractions }\end{array}$ & & 0.700 & 11.896 & & \\
\hline SERV3 & $\begin{array}{l}\text { Availability and Safety of } \\
\text { money and banking facility }\end{array}$ & & 0.810 & 12.225 & & \\
\hline \multicolumn{2}{|c|}{ Destination softscape quality } & & & & & \\
\hline \multirow[b]{2}{*}{ SERV4 } & \multirow{2}{*}{$\begin{array}{l}\text { Friendliness -Hospitality of } \\
\text { people in the destination }\end{array}$} & & 0.920 & 20.54 & & \\
\hline & & & \multirow[b]{2}{*}{0.904} & \multirow[b]{2}{*}{20.54} & & \\
\hline SERV5 & $\begin{array}{l}\text { The residents of the } \\
\text { destination are good and } \\
\text { welcoming to tourists }\end{array}$ & & & & & \\
\hline \multicolumn{2}{|c|}{ Informational service completeness } & & & & 0.710 & 0.907 \\
\hline
\end{tabular}




\begin{tabular}{|c|c|c|c|c|c|c|}
\hline $\begin{array}{l}\text { Variable } \\
\text { and } \\
\text { Indicator } \\
\text { code }\end{array}$ & Scales Item & Reference & $\begin{array}{l}\text { Standard } \\
\text { Loading }\end{array}$ & $\begin{array}{c}\text { Critical } \\
\text { Ratio } \\
\geq 1.96\end{array}$ & $\begin{array}{c}\text { CV- } \\
\text { AVE } \\
\geq 0.50\end{array}$ & $\begin{array}{l}\text { CRI } \\
\geq 0.70\end{array}$ \\
\hline \multirow[b]{2}{*}{ ISC1 } & \multirow{2}{*}{$\begin{array}{l}\text { Availability of prior } \\
\text { cultural information }\end{array}$} & \multirow{5}{*}{$\begin{array}{c}\text { Adapted from } \\
\text { Oviedo-García, } \\
\text { Vega-Vázquez, } \\
\text { Castellanos- } \\
\text { Verdugo, \& } \\
\text { Orgaz-Agüera, } \\
\text { 2019; Wang \& } \\
\text { Mattila, } 2011\end{array}$} & 0.800 & 6.641 & & \\
\hline & & & \multirow{2}{*}{0.843} & \multirow{2}{*}{6.169} & & \\
\hline ISC2 & $\begin{array}{l}\text { Experiencing accuracy of } \\
\text { clear information }\end{array}$ & & & & & \\
\hline ISC3 & $\begin{array}{l}\text { Clear information and } \\
\text { provided properly }\end{array}$ & & 0.892 & 6.406 & & \\
\hline ISC4 & $\begin{array}{l}\text { The information provided } \\
\text { is adequate, more than } \\
\text { expected }\end{array}$ & & 0.834 & 6.406 & & \\
\hline \multicolumn{2}{|c|}{ Destination congruity } & \multirow{4}{*}{$\begin{array}{l}\text { Adapted from } \\
\text { Shin, Lee, \& } \\
\text { Perdue, 2018; } \\
\text { and Ahn, T., } \\
\text { Ekinci, Y., \& Li, } \\
\text { G, } 2013\end{array}$} & & & 0.824 & 0.934 \\
\hline DC1 & $\begin{array}{l}\text { My self-image fits the } \\
\text { image of the destination \& } \\
\text { event well. }\end{array}$ & & 0.885 & 23.882 & & \\
\hline DC2 & $\begin{array}{l}\text { I feel like I am a part of the } \\
\text { event }\end{array}$ & & 0.937 & 23.882 & & \\
\hline DC3 & $\begin{array}{l}\text { Participating in many } \\
\text { events in this destination } \\
\text { reflects who I am }\end{array}$ & & 0.901 & 25.751 & & \\
\hline \multicolumn{2}{|c|}{$\begin{array}{l}\text { Destination authentic } \\
\text { value advantage }\end{array}$} & \multirow{5}{*}{$\begin{array}{c}\text { Newly } \\
\text { developed, } \\
\text { adapted from } \\
\text { (Fu, Liu, Wang, } \\
\text { \& Chao, 2018; } \\
\text { Jang \& Ha, } \\
\text { 2015; Lu, Chi, } \\
\text { \& Liu, 2015) }\end{array}$} & & & 0.515 & 0.809 \\
\hline ADV1 & $\begin{array}{l}\text { This destination is rich in } \\
\text { natural scenery } \\
\text { authenticity }\end{array}$ & & 0.719 & 11.307 & & \\
\hline ADV2 & $\begin{array}{l}\text { Compared to others, this } \\
\text { destination authenticity is } \\
\text { well maintained and } \\
\text { preserved }\end{array}$ & & 0.692 & 11.307 & & \\
\hline ADV3 & $\begin{array}{l}\text { This destination has a } \\
\text { superior fauna \&flora } \\
\text { collection }\end{array}$ & & 0.679 & 11.12 & & \\
\hline ADV4 & $\begin{array}{l}\text { I see so many specific } \\
\text { authenticy in this } \\
\text { destination compared to } \\
\text { others }\end{array}$ & & 0.776 & 12.538 & & \\
\hline \multicolumn{2}{|r|}{ Destination loyalty } & \multirow{4}{*}{$\begin{array}{l}\text { Adapted from } \\
\text { Tosun, } \\
\text { Dedeoğlu, \& } \\
\text { Fyall, 2015; } \\
\text { Dedeoğlu, } \\
\text { 2019; and } \\
\text { Sangpikul, } \\
\text { 2018, } \\
\text { Akroush, } \\
\text { Jraisat, } \\
\text { Kurdieh, Al- } \\
\text { Faouri, \& Qatu, } \\
\text { 2016 }\end{array}$} & & & 0.879 & 0.709 \\
\hline DL1 & $\begin{array}{l}\text { I would advise } \\
\text { /recommend other people } \\
\text { to visit this destination }\end{array}$ & & 0.935 & 17.712 & & \\
\hline DL2 & $\begin{array}{l}\text { If I have to decide again for } \\
\text { coming together with my } \\
\text { family, I would choose this } \\
\text { place again. }\end{array}$ & & 0.784 & 17.712 & & \\
\hline DL3 & $\begin{array}{l}\text { I would more frequently } \\
\text { visit this place }\end{array}$ & & 0.799 & 18.274 & & \\
\hline \multicolumn{3}{|c|}{ CV-AVE = Convergent Validity } & & & & \\
\hline \multicolumn{3}{|c|}{ CRI = Construct Reliability Index } & & & & \\
\hline
\end{tabular}


Source: Authors' own research.

A two-step analysis of AMOS SEM version 23 is conducted - the confirmatory factor analysis (CFA), followed by a full-structural model. The CFA result fulfils the minimum expected value of 0.50 for each construct, with a minimum significant critical ratio of 1.96 (Arbuckle, 2016) as Table 3 presents; therefore, it is accepted for further analysis. All the model constructs have acceptable convergent validity, measured by average variance extracted (AVE) with the cut-off value of a minimum of 0.50 . Our CFA indicated that destination servicescape quality achieved its cut-off value with an AVE value of 0.682 . We obtained the same result for Destination authentic value advantage (0.515), Destination congruity (0.824), Informational service completeness (0.710), and Destination loyalty $(0,879)$. The CRI-construct reliability index measures the construct reliability with a minimum cut-off value of 0.70 (Tabachnick \& Fidell, 2012). Our calculation indicated a good level of reliability, in that Destination servicescape quality has a CRI of 0.914 , as did the values for Destination authentic value advantage (0.809), Destination congruity (0.934), Informational service completeness (0.907), and Destination loyalty (0.709). As the validity and reliability of all constructs match the minimum requirement, indicating good data for the model conclusion, we continued to the full structural equation modeling procedure for testing the proposed hypotheses.

\section{Hypothesis Testing}

A three-step analysis was conducted, first is to analyse the goodness-of-fit statistics for testing whether the sampled data confirm the model. The analysis evaluated statistical measures to reach a significant level of chi-square $\geq 0.05$; unfortunately, this requirement is not met. Referring to Arbuckle (2016) and Tabachnick and Fidell (2012), as chi-square significance is sensitive to the sample size, the goodness-of-fit test, a nonstatistical measure, could be used. The goodness-of-fit test demonstrated good and acceptable criteria with a level of GFI $=0.901 ; \mathrm{NFI}=0.927 ; \mathrm{TLI}=0.949 ; \mathrm{CFI}=0.957$ and $\mathrm{RMSEA}=0.064$, as Table 4 shows, indicating all cut-off values are met (Arbuckle, 2016).

Table 4. Model Testing

\begin{tabular}{|l|c|c|c|}
\hline \multicolumn{1}{|c|}{ The goodness of fit Test } & Cut-off Value & Result & Conclusion \\
\hline Chi-square for DF=144 at a significance level 5\% & 331.19 & 173.00 & Not Fit \\
\hline Significance & $\geq 0.05$ & 0.00 & Not Fit \\
\hline The Goodness of Fit Index & $\geq 0.90$ & 0.90 & Fit \\
\hline The Normed Fit Index & $\geq 0.90$ & 0.93 & Fit \\
\hline Comparative Fit Index & $\geq 0.90$ & 0.96 & Fit \\
\hline Tucker Lewis Index & $\geq 0.90$ & 0.95 & Fit \\
\hline RMSEA-Root mean square error of approximation & $0.03-0.08$ & 0.06 & Fit \\
\hline
\end{tabular}

Source: Authors' own research. 


\section{Model Testing}

The second step is testing the acceptance of our regression hypotheses.

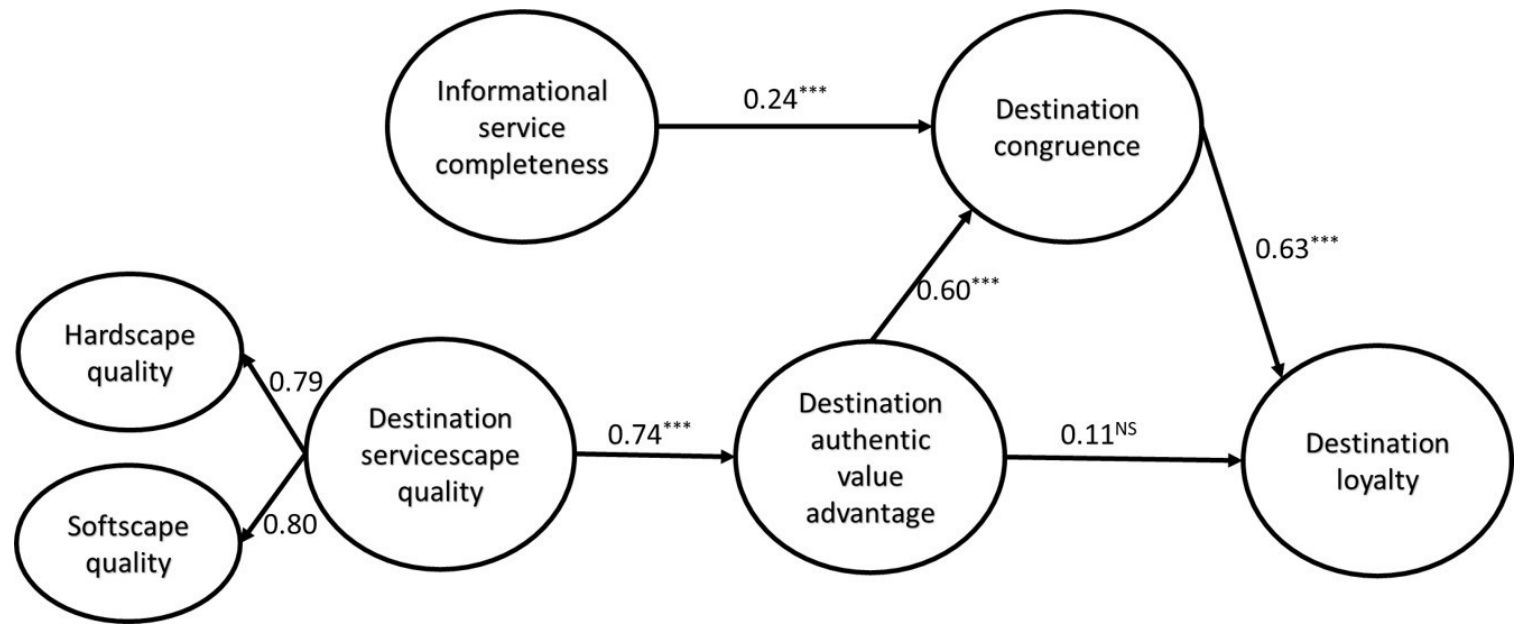

Figure 2. The full structural model

Source: Authors' own research.

Table 5. Hypothesis testing

\begin{tabular}{|c|c|c|c|c|c|c|}
\hline \multicolumn{2}{|r|}{ Hypotheses } & $\begin{array}{c}\text { Std. } \\
\text { Estimate }\end{array}$ & Estimate & CR & $\mathbf{P}$ & Conclusion \\
\hline H1 & $\begin{array}{l}\text { Destination servicescape } \\
\text { quality } \rightarrow \text { destination authentic value } \\
\text { advantage. }\end{array}$ & 0.740 & 0.852 & 8.270 & $* * *$ & Accepted \\
\hline $\mathrm{H} 2$ & $\begin{array}{l}\text { Destination authentic value } \\
\text { advantage } \rightarrow \text { destination loyalty }\end{array}$ & 0.114 & 0.161 & 1.347 & 0.178 & Rejected \\
\hline H3 & $\begin{array}{l}\text { Destination authentic value } \\
\text { advantage } \rightarrow \text { destination congruity }\end{array}$ & 0.599 & 0.767 & 7.737 & *** & Accepted \\
\hline $\mathrm{H} 4$ & $\begin{array}{l}\text { Informational service } \\
\text { completeness } \rightarrow \text { destination } \\
\text { congruence }\end{array}$ & 0.239 & 0.255 & 3.648 & *** & Accepted \\
\hline H5 & $\begin{array}{l}\text { Destination congruence } \rightarrow \\
\text { destination loyalty. }\end{array}$ & 0.625 & 0.688 & 7.536 & $* * *$ & Accepted \\
\hline \multirow[t]{2}{*}{ H6 } & $\begin{array}{l}\text { Destination authentic value } \\
\text { mediated the influence of } \\
\text { destination servicescape to } \\
\text { destination loyalty } \\
\text { Step 1: Destination servicescape } \\
\text { quality } \rightarrow \text { destination authentic value } \\
\text { advantage. }\end{array}$ & 0.740 & 0.852 & 8.270 & *** & Accepted \\
\hline & $\begin{array}{l}\text { Step 2: Destination authentic value } \\
\text { advantage } \rightarrow \text { destination loyalty }\end{array}$ & 0.114 & 0.161 & 1.347 & 0.178 & Rejected \\
\hline $\mathrm{H} 7$ & $\begin{array}{l}\text { Destination congruence mediates } \\
\text { the influence of destination } \\
\text { authentic value advantage to } \\
\text { destination loyalty }\end{array}$ & & & & & \\
\hline
\end{tabular}




\begin{tabular}{|c|l|c|c|c|c|c|}
\hline \multicolumn{2}{|c|}{ Hypotheses } & $\begin{array}{c}\text { Std. } \\
\text { Estimate }\end{array}$ & Estimate & CR & P & Conclusion \\
\hline \multirow{2}{*}{$\begin{array}{l}\text { Step 1: Destination authentic value } \\
\text { advantage } \rightarrow \text { destination loyalty } \\
\text { Step 2: Destination authentic value } \\
\text { advantage } \rightarrow \text { destination } \\
\text { congruence }\end{array}$} & 0.569 & 0.788 & 0.910 & $* * *$ & Accepted \\
\cline { 2 - 6 } \\
$\begin{array}{l}\text { Step 3: Destination congruence } \rightarrow \\
\text { Destination loyalty } \\
\text { Step 4: Destination authentic value } \\
\text { advantage } \rightarrow \text { Destination loyalty }\end{array}$ & 0.752 & 0.949 & 11.398 & $* * *$ & Accepted \\
\cline { 2 - 6 } & 0.089 & 0.122 & 1.046 & 0.295 & Rejected \\
\hline
\end{tabular}

Source: Authors' own research.

As Table 5 shows, all hypotheses were accepted, except hypothesis 2 which was rejected. The rejection of Hypothesis 2 automatically nullifies the significance of inserting the mediation hypothesis that destination authentic value advantage mediates destination servicescape's influence on destination loyalty in the model. Therefore, hypothesis number 2 and hypothesis number 6 are rejected.

We adopt the Baron and Kenny's (1986) procedure of four-step testing of the mediation hypothesis, resulting in a significant regression weight of independent variable to dependent variable (0.569). The second step is to confirm the independent variable's significance to the mediation variable, resulting in a significant regression weight of 0.752 . The third step is to run a model for the mediation variable's regression to the dependent variable, resulting in a significant regression weight of 0.709 . The last step is to rerun the independent variable's regression to the dependent variable, inserting the mediation variable. Suppose the independent variable's regression weight to the dependent variable is reduced or insignificant; when the mediation variable is inserted, the conclusion will be the existence of a full mediation effect. Our final step is to see that regression weight reduces to 0.089 , is not significant, indicating the existence of a full mediation effect.

\section{Discussion of the result}

This study revealed several significant findings explaining how destination servicescape quality enhances visitor loyalty to revisit or recommend exploring the visited destination to others. One of this study's essential findings is confirming two symmetric dimensions of a destination servicescape: destination hard-servicescape and destination soft-servicescape, as a portfolio of maintaining services as marketing capital. For tourism companies, DSQ is an asset to create value, while for tourists, DSQ is a lever for strengthening the values a tourist experiencingduring the visit. As expected through our hypothesis development, SDL emphasises the importance of value and value advantage as drivers for sustaining marketing performance (Lu \& Yuwen Shiu, 2009; Vargo \& Lusch, 2017). The current research demonstrates the importance of the development of servicescape for enhancing destination value advantage, supporting the notion of servicescape's role to leverage service experience quality (Tran Quynh et al., 2020). Our finding pinpointed the significant role of destination servicescape in enhancing the positive consumption memory, the result of experiencing authentic value advantage at a destination. 
The rejection of our mediating hypothesis, namely, that the destination authentic value advantage mediates the influence of destination servicescape on destination loyalty, proved our argument that economic rationality will lead a tourist not to spend money on returning or, as mentioned by Correia et al. (2015), a tourist has less possibility of returning to the same destination. Therefore, we posit that any destination value advantage may enhance loyalty behavior if experiencing any specific authentic value in a destination succeeds in enhancing a feeling of congruity. The acceptance of our mediating hypothesis that destination congruence mediates destination authentic value advantage effects on destination loyalty could be interpreted as follows. If a tourist experiences any advantages of the authentic value that evoke a feeling of congruity, this positive experience could lead to the possibility of returning to the visited places. If it fails to enhance a level of congruity, then the superiority of authentic value may result in less capability to enhance loyalty. The acceptance of the hypothesis of the influence of destination servicescape quality on authentic value advantage strengthens the notion that DAVA is a crucial driver for sustaining consumer-side marketing performance.

Our study provides strong evidence that DAVA is the key to the sustainability of tourism marketing from consumer perspectives on making travel decisions and loyalty. Spending rationality will lead tourists to find new tourist objects to visit unless DAVA can provide a certain congruity. Why? Spending rationality and consumption priority will direct tourists to diversify for desire-based diversity unless a congruity-based positive emotion appears at the time of a visit. Our study reveals that because DSQ is a lever of the process of experiencing a superior value, a complete set of information will drive demand and resonate with destination quality. In a nutshell, the essence of SDL in destination and tourism study is that value creation, including unique-authentic values, is a vital value hub. Value hubs themselves cannot create loyalty because of spending rationality unless they hold the potential to drive a feeling of congruity. This study provides a perspective on the power of a valued hub in a destination marketing process.

\section{Conclusion}

The current study aims to fill up the research gap on the inconsistent finding of the previous study of the influence of destination service-scape quality for enhancing destination loyalty. Our research findings conclude the importance of destination authentic value advantage and destination congruence as critical strategic leverage for enhancing destination loyalty. Destination authentic value advantage is one of the influential power to impact visitor loyalty behaviour (Thomas-Francois et al., 2017) lead to enhance destination congruence as proved in this study. Spending rationality may lead to a decition for seeking a variety in other destinations, but when a destination is capable of providing a kind of emotional value (Sharma \& Nayak Jogendra, 2019), through its value authenticity, then decision to return of destination loyalty may happen.

\section{Theoretical implication}

This research is rooted in SDL as primary for creating value in a business; value is the key to success and sustainability (Vargo \& Lusch, 2017). Strengthening the SDL application, the current study contributes to developing the two symmetrical attributes of a service, hardservicescape and soft-servicescape. The quality of the servicescape is a potential driving force for a superior service image (SDL). This study also makes a conceptual contribution, namely, 
that the value in SDL will become meaningful if this value is experienced and perceived as an advantage, notably as a series of advantages in authenticity, created and co-created in the SDL conception. Third, this study contributes to applying self-congruence theory (Sirgy, 1982; Sirgy \& Su, 2016), with a requirement for its ability to signal the formation of congruency and be effectively congruent to the visitors, as a consequence of the strength of information and services (SDL). The service advantage-based congruity is a trigger for consumers' or tourists' loyalty.

\section{Managerial implication}

This study provides several managerial implications for the development of tourism marketing. First, considering the magnitude of destination servicescape quality's loading factor, a managerial implication arises. A company wishing to develop its destination services must give equal attention to developing destination hardscape and soft-scape. Therefore, the development of a destination's physical environment should be in tune with developing its emotional-social environment, to become a tool for increasing the power of destination authenticity offered to the consumer market. Second, like the SDL spirit, what consumers seek is not a product or service but an attractive, authentic value. Therefore, the destination manager should always develop and perpetuate the destination's authenticity, such as preserved natural beauty, specific cultural peculiarities, and unique flora and fauna collections, to provide superior destination value for tourists. Third, to increase destination loyalty, companies should provide services that can encourage positive emotions as the basis for building congruency, such as the beauty of the attractions presented, providing space for interaction and attachments for tourists, as well as excellent and complete information without complications. These policies would promote congruence with the tourist's willingness to recommend this tourist spot to family and acquaintances.

\section{Research limitation and venue for further research}

Even though the research findings evoke several contributions in the destination-marketing literature, some limitations still exist. This study was conducted using convenience sampling because of the unknown population size in a large coverage area, calling for care in generalising. Our sample frame is covered only Indonesian destination and visitors; therefore, the generalizability of this study is limited to Indonesia. Second, even though this study was conducted with a robust logical theory, the rejection of the hypothesis regarding the authentic value destination effect on loyalty provides various interpretations for further research. First, what kind of values are more capable of increasing loyalty? Second, what conceptual bridge should be further explored to drive destination value and increase loyalty to a destination, given the fact that our common rationality in spending would limit the priority of revisiting and direct us toward visiting another new place or destination. Third, the rejection of the hypothesis of authentic value advantage for enhancing destination loyalty creates a new research gap that further research may fill. Fourth, As the COVID-10 pandemic has had a significant impact on Tourism worldwide and particularly in Indonesia, a future study might be directed to insert the Covid19 pandemic as a moderator for enhancing loyalty. 


\section{References}

Abodeeb, J., Wilson, E., \& Moyle, B. (2015). Shaping destination image and identity: insights for Arab tourism at the Gold Coast, Australia. International Journal of Culture, Tourism and Hospitality Research, 9(1): 6-21.

Ahn, T., Ekinci, Y., \& Li, G. (2013). Self-congruence, functional congruence, and destination choice. Journal of Business Research, 66(6): 719-723.

Akroush, M. N., Jraisat, L. E., Kurdieh, D. J., Al-Faouri, R. N., \& Qatu, L. T. (2016). Tourism service quality and destination loyalty - the mediating role of destination image from international tourists' perspectives. Tourism Review, 71(1): 18-44.

Alazaizeh, M. M., Hallo, J. C., Backman, S. J., Norman, W. C., \& Vogel, M. A. (2016). Value orientations and heritage tourism management at Petra Archaeological Park, Jordan. Tourism Management, 57: 149-158.

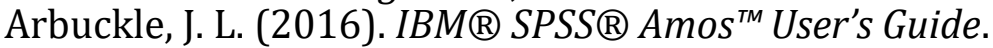

Beerli, A., Meneses, G. D., \& Gil, S. M. (2007). Self-congruity and destination choice. Annals of Tourism Research, 34(3): 571-587.

Botschen, G., Promberger, K., \& Bernhart, J. (2017). Brand-driven identity development of places. Journal of Place Management and Development, 10(2): 152-172.

Chang, L.-L., F. Backman, K., \& Chih Huang, Y. (2014). Creative tourism: a preliminary examination of creative tourists' motivation, experience, perceived value and revisit intention. International Journal of Culture, Tourism and Hospitality Research, 8(4): 401-419.

Choi, S. h., \& Wu, H. C. (2018). Tourism communicative actions of sojourners and information recipients. Journal of Destination Marketing \& Management, 9: 279-287.

Correia, A., Zins, A. H., \& Silva, F. (2015). Why Do Tourists Persist in Visiting the Same Destination? Tourism Economics, 21(1): 205-221.

Cracolici, M. F., \& Nijkamp, P. (2009). The attractiveness and competitiveness of tourist destinations: A study of Southern Italian regions. Tourism Management, 30(3): 336344.

Dedeoğlu, B. B. (2019). Shaping tourists' destination quality perception and loyalty through destination country image: The importance of involvement and perceived value. Tourism Management Perspectives, 29: 105-117.

Evans, N. G. (2016). Sustainable competitive advantage in tourism organisations: A strategic model applying service dominant logic and tourism's defining characteristics. Tourism Management Perspectives, 18: 14-25.

Ferreira, P., Rodrigues, P., \& Rodrigues, P. (2019). Brand Love as Mediator of the Brand Experience-Satisfaction-Loyalty Relationship in a Retail Fashion Brand. Management \& Marketing. Challenges for the Knowledge Society, 14(3): 278-291.

$\mathrm{Fu}, \mathrm{X}$. (2019). Existential authenticity and destination loyalty: Evidence from heritage tourists. Journal of Destination Marketing \& Management, 12: 84-94.

Fu, Y., Liu, X., Wang, Y., \& Chao, R.-F. (2018). How experiential consumption moderates the effects of souvenir authenticity on behavioral intention through perceived value. Tourism Management, 69: 356-367.

Greer, C. R., Lusch, R. F., \& Vargo, S. L. (2016). A service perspective. Organizational Dynamics, 45(1): 28-38.

Haziri, F., Chovancová, M., \& Fetahu, F. (2019). Game mechanics and aesthetics differences for tangible and intangible goods provided via social media. Management \& Marketing. Challenges for the Knowledge Society, 14(2): 176-187.

Hossain, M. E., Quaddus, M., \& Shanka, T. (2015). Effects of Intrinsic and Extrinsic Quality Cues and Perceived Risk on Visitors' Satisfaction and Loyalty. Journal of Quality Assurance in Hospitality \& Tourism, 16(2): 119-140.

Hunt, S. D., \& Arnett, D. B. (2006). Does marketing success lead to market success? Journal of Business Research, 59(7): 820-828. 
Iordanova, E., \& Stylidis, D. (2019). The impact of visitors' experience intensity on in-situ destination image formation. Tourism Review, 74(4): 841-860.

Jang, S., \& Ha, J. (2015). The Influence of Cultural Experience: Emotions in Relation to Authenticity at Ethnic Restaurants. Journal of Foodservice Business Research, 18(3): 287-306.

Kaushal, V., Sharma, S., \& Reddy, G. M. (2018). A structural analysis of destination brand equity in mountainous tourism destination in northern India. Tourism and Hospitality Research, 19(4): 452-464.

Kim, O. Y., Seo, S., \& Nurhidayati, V. A. (2019). Scale to measure tourist value of destination restaurant service. International Journal of Contemporary Hospitality Management, 31(7): 2827-2844.

Kim, S., Lehto, X., \& Kandampully, J. (2019). The role of familiarity in consumer destination image formation. Tourism Review, 74(4): 885-901.

Liu, C.-R., Lin, W.-R., \& Wang, Y.-C. (2012). Relationship between self-congruity and destination loyalty: Differences between first-time and repeat visitors. Journal of Destination Marketing \& Management, 1(1-2): 118-123.

Lockwood, A., \& Pyun, K. (2020). Developing a scale measuring customers' servicescape perceptions in upscale hotels. International Journal of Contemporary Hospitality Management, 32(1): 40-59.

Lojo, A., Li, M., \& Xu, H. (2020). Online tourism destination image: components, information sources, and incongruence. Journal of Travel \& Tourism Marketing, 37(4): 495-509.

Lu, I. Y., \& Yuwen Shiu, J. (2009). Customers' Behavioral Intentions in the Service Industry: An Empirical Study of Taiwan Spa Hotels. Asian Journal on Quality, 10(3): 73-85.

Lu, L., Chi, C. G., \& Liu, Y. (2015). Authenticity, involvement, and image: Evaluating tourist experiences at historic districts. Tourism Management, 50: 85-96.

Mikulić, J., Krešić, D., Prebežac, D., Miličević, K., \& Šerić, M. (2016). Identifying drivers of destination attractiveness in a competitive environment: A comparison of approaches. Journal of Destination Marketing \& Management, 5(2): 154-163.

Nunnally, J. C., \& Bermstein, I. H. (1994). Psychometric Theory (Third ed.). New York: McGraw-Hill.

Oviedo-García, M. Á., Vega-Vázquez, M., Castellanos-Verdugo, M., \& Orgaz-Agüera, F. (2019). Tourism in protected areas and the impact of servicescape on tourist satisfaction, key in sustainability. Journal of Destination Marketing \& Management, 12: 74-83.

Ramkissoon, H., \& Nunkoo, R. (2011). City Image and Perceived Tourism Impact: Evidence from Port Louis, Mauritius. International Journal of Hospitality \& Tourism Administration, 12(2): 123-143.

Rather, R. A., Najar, A. H., \& Jaziri, D. (2020). Destination branding in tourism: insights from social identification, attachment and experience theories. Anatolia, 31(2): 229-243.

Richardson, S., Lefrid, M., Jahani, S., Munyon, M. D., \& Rasoolimanesh, S. M. (2019). Effect of dining experience on future intention in quick service restaurants. British Food Journal, 121(11): 2620-2636.

Saikia, J., Buragohain, P. P., \& Choudhury, H. K. (2019). Attribute perception and tourist's choice for wildlife tourism destination. International Journal of Culture, Tourism and Hospitality Research, 13(3): 346-358.

Sangpikul, A. (2018). The effects of travel experience dimensions on tourist satisfaction and destination loyalty: the case of an island destination. International Journal of Culture, Tourism and Hospitality Research, 12(1): 106-123.

Sharma, P., \& Nayak Jogendra, K. (2019). Dark tourism: tourist value and loyalty intentions. Tourism Review, 74(4): 915-929.

Shin, H., Lee, H., \& Perdue, R. R. (2018). The congruity effects of commercial brand sponsorship in a regional event. Tourism Management, 67: 168-179.

Sirgy, M. J. (1982). Self-Concept in Consumer Behavior: A Critical Review. Journal of Consumer Research, 9(3): 287-300. 
Sirgy, M. J., \& Su, C. (2016). Destination Image, Self-Congruity, and Travel Behavior: Toward an Integrative Model. Journal of Travel Research, 38(4): 340-352.

Suhartanto, D., Brien, A., Primiana, I., Wibisono, N., \& Triyuni, N. N. (2019). Tourist loyalty in creative tourism: the role of experience quality, value, satisfaction, and motivation. Current Issues in Tourism, 23(7): 867-879.

Tabachnick, B. G., \& Fidell, L. S. (2012). Using Multivariate Statistics (6 ed.). New York: Pearson Publisher.

Thomas-Francois, K., von Massow, M., \& Joppe, M. (2017). Service-oriented, sustainable, local food value chain - A case study. Annals of Tourism Research, 65: 83-96.

Tosun, C., Dedeoğlu, B. B., \& Fyall, A. (2015). Destination service quality, affective image and revisit intention: The moderating role of past experience. Journal of Destination Marketing \& Management, 4(4): 222-234.

Tran Quynh, X., Dang My, V., \& Tournois, N. (2020). The role of servicescape and social interaction toward customer service experience in coffee stores. The case of Vietnam. International Journal of Culture, Tourism and Hospitality Research, 14(4): 619-637.

Tubillejas Andrés, B., Cervera-Taulet, A., \& Calderón García, H. (2016). Social servicescape effects on post-consumption behavior: The moderating effect of positive emotions in opera-goers. Journal of Service Theory and Practice, 26(5): 590-615.

Vargo, S. L., \& Lusch, R. F. (2017). Service-dominant logic 2025. International Journal of Research in Marketing, 34(1): 46-67.

Wang, C. y., \& Mattila, A. S. (2011). A cross-cultural comparison of perceived informational fairness with service failure explanations. Journal of Services Marketing, 25(6): 429439.

Zhang, H., Wu, Y., \& Buhalis, D. (2018). A model of perceived image, memorable tourism experiences and revisit intention. Journal of Destination Marketing \& Management, 8: 326-336.

Zhang, Q., \& Xu, H. (2020). Understanding aesthetic experiences in nature-based tourism: The important role of tourists' literary associations. Journal of Destination Marketing \& Management, 16.

Ziakas, V., Shipway, R., \& Boukas, N. (2012). A neglected legacy. International Journal of Event and Festival Management, 3(3): 292-316. 